\title{
Madame Maria Sklodowska-Curie - brilliant scientist, humanitarian, humble hero: Poland's gift to the World
}

\author{
Mark Trombetta, MD, FACR \\ 'Department of Radiation Oncology, Allegheny General Hospital, Pittsburgh, USA, ${ }^{2}$ Drexel University College of Medicine, Allegheny \\ Campus, Pittsburgh, USA, ${ }^{3}$ Temple University School of Medicine, Pittsburgh Campus, Pittsburgh, USA
}

\begin{abstract}
In 1911, when the Nobel Foundation awarded its coveted Chemistry Prize to a 44 year old Polish born woman, it is likely they may not have expected the action ever duplicated in the more than 100 years that followed. In fact, it was the second Nobel Prize in the sciences awarded to Maria Sklodowska-Curie, whom the world would come to admire, know, and love as Madame Curie. In a time of science dominated by men, the diminutive in size but larger-than-life Curie would become the first women to be awarded the prize. To this date, she remains the only person in history to win two Nobel prizes in two different science fields, and only one of four persons to win more than one. In total, Mme. Curie and her immediate family would be awarded five Nobel prizes. As astonishing as these facts may be, Mme. Curie did not seek fame nor did she seek self aggrandizement. Her whole life was one of service to humanity, an indefatigable work ethic, and humility.
\end{abstract}

J Contemp Brachytherapy 2014; 6, 3: 297-299 DOI: 10.5114/jcb.2014.45133

Key words: Maria Sklodowska-Curie, brachytherapy, radium, history.

Maria Sklodowska was born in partitioned Poland (in the city of Warsaw) in 1867 of humble means. Maria was the youngest of five children born to two respected teachers (her father an atheist and her mother a devout Roman catholic), whose families were economically devastated by their patriotic involvement in the struggle for Polish independence; patriotism instilled into the young woman by her parents, which would re-emerge later in life. The young Sklodowska's life would chance dramatically with the death of both her mother (tuberculosis) and her sister (typhus) by the time Maria reached age 10. In June of 1883, Maria graduated from a girl's school with a gold medal award. Soon afterward, she was affected by a medical illness, which has been characterized as possibly depression, and spent approximately one year in recovery with relatives in the rural surrounds of Warsaw. Maria then attended the now well-known Uniwersytet Latajacy (the Flying University), an "underground" patriotic university in Warsaw, which operated from 1885-1905 to educate Polish youth in a traditional manner and without governmental censorship. The Flying University was particularly important for young Maria, since the education of women was prohibited under the oppressive Russian occupation. Maria and her sister, Bronislawa, would enter into a pact to assist each other in completing their studies of higher education, which would occur for Maria in Paris at her sister's urging.
The formal education at the University of Paris (la Sorbonne) was difficult for the young Sklodowska. Her studies were intense, but she was well prepared and brilliant. Her sustenance was sporadic and she often suffered from hunger and cold exposure, as she earned barely enough money to live by tutoring. In 1893 she earned her degree in physics and went on to earn a second degree in mathematics the next year. Maria lacked laboratory space for her research, and Polish physicist Josef Kowalski-Wierusz introduced her to a young scientist with extra lab space. That scientist was Pierre Curie. Passionate scientists both, Pierre would propose marriage to Maria soon afterward, but she would not immediately accept. It is reported that she dreamed of returning to Poland to pursue her research, however she would later convince Pierre to finish his doctoral studies in magnetism and, at her urging, he did so and was awarded his degree. Finally, Maria would write: "Our work drew us closer and closer, until we were both convinced that neither of us could find a better life companion". They were married and, true to her practical and humble nature, the dark blue wedding dress that she wore to the civil ceremony would become her lab coat for many years to come.

Following the discovery of X-rays by Wilhelm Roentgen and the first observations of radioactivity by Henri Becquerel, Maria became interested in this new field. She constructed a hypothesis that this radiation came from 
the atom itself as a type of disintegration while the commonly held belief stressed the indivisibility of the atom. Using pitchblende, a mineral found in abundance in east central Europe, the Curies (Pierre soon joined her in her work) discovered the first radioactive element, polonium. Never forgetting her Polish heritage and the struggle for independence, Maria humbly asked Pierre if he would agree to name the substance polonium to bring awareness to her own homeland, which had been removed from the map and divided by the occupying nations of Czarist Russia, Austria, and Germany. He agreed. In the Proceedings of the Academy of Science July 18, 1898, she would write: "...We propose to call it polonium from the name of the original country of one of us". With that single statement, she would raise awareness of the struggle for independence in her beloved Poland and inspire her countrymen. Poland would regain her independence in 1918 following World War I, and the discovery of radium would occur 5 months later. By the early 1900's, physicians announced the successful treatment of cancers with radium. In 1903, Maria Sklodowska-Curie received her doctorate from the University of Paris, and she and Pierre were asked to speak on radioactivity (the new term coined by Curie) at the Royal Institution in London. Because of the prohibition against women speaking at the Institution, Pierre gave the address. However, later that year, both Pierre and Maria Curie would be invited to the Royal Swedish Academy of Sciences to receive the Nobel prize in physics along with Henri Becquerel. Again, this was not without controversy, as the Academy originally decided to exempt Mme. Curie from the award until Swedish mathematician and women's advocate Magnus Goesta Mittag-Lefffler contacted Pierre. Maria Curie became the first woman to receive the Nobel prize, however the Curies decided not to attend the ceremony as they disliked the spotlight and wished to continue their work uninterrupted. Tragedy struck in 1906 as Pierre was killed in an accident leaving Maria despondent and caring for two young daughters. She had always been a working mother devoted to her children, but now had to assume both roles. The University of Paris offered her Pierre's chair in the physics department, making her the first woman professor in its history. Shortly afterward, she was able to isolate radium for the first time and developed an international standard for radioactive decay, which bears her name to this day. The unit was originally defined as the amount of radon in equilibrium with $10^{-8}$ grams of radium, but Maria was not in agreement with this decision as she wanted a gram-based standard. A tough negotiator, the committee relented and the standard was set according to her wishes. Despite her great accomplishments, the fact that she was a woman in what was considered to be a man's field, continued to serve as the source for a number of jealous colleagues to discriminate against her. Putting aside these issues, Mme. Curie did not allow distraction and continued her work, and in 1911 was awarded the second Nobel prize - this time in chemistry. For Maria, this was gratifying, but she did not seek the fame that she had earned now as the premier scientist in the World.

In 1913 the Polish people got a firsthand view of the greatest scientist of the day and highly favored daughter when she triumphantly returned to Warsaw for a hero's welcome. Her visit to her homeland would not last long. The "Great War" would break out and Professor Curie would respond to the needs of the Allied forces by developing a network of battlefield radiological stations. She would write: "I am resolved to put all my strength at the service of my adopted country, since I cannot do anything for my unfortunate native country now". In the midst of the greatest war the world had ever seen, this loving mother would calm and inspire her children. She would write: "We must keep firm hope that after these bad days, good times will return. It's in that hope that I lock you in my heart, my beloved daughters". Curie was instrumental in the invention of mobile X-ray units reverently named "petite Curies" by the medical corps and estimated to have aided in the care of one million of the approximately 42 million Allied troops. Additionally, she helped develop radon needles crafted from her precious limited supply of radium to aid in infection control. The brilliant scientist would become a brilliant civilian war hero.

Professor Curie shunned fame as a self-serving vehicle and she routinely donated her prize money refusing many prestigious and meritorious awards, even to the point of attempting to donate her gold medals to further humanitarian causes and the war effort. She would even repay the initial student loan from the University of Paris as she shunned material wealth with all humility. However, to continue her research efforts she would embark on a trip to the United States to accept an additional gram of radium to further her work. When she arrived in New York City, she was greeted by thousands upon thousands of women and young girls who lined the streets to get a glimpse of this contemporary hero. Mme. Curie was overwhelmed by the reception as her humble nature could not quite comprehend the outpouring of affection. President Harding met with Professor Curie to deliver the gram of radium as a gift from the women of the United States who had formed the Marie Curie Radium Fund. The gram of radium had been laborious retrieved from carnotite by the Standard Chemical company of Pittsburgh, Pennsylvania. Professor Curie was so impressed by the work involved (hundreds of thousands of man-hours), that during her short visit to America, she asked to visited the small town of Canonsburg (a suburb of Pittsburgh) to view the exact site of the work to pay tribute to the workers who had given their labor. Returning to her research after the war, she would continue the development of the Radium Institute in Paris and found the Warsaw Radium Institute in her native Poland. She worked constantly until she began to suffer fatigue from what was later diagnosed as aplastic anemia. In a strange irony, a disease liked caused by radiation exposure would take the life of the woman whose greatest accomplishments revolved around a substance that would be used first by her to cure malignancies in innumerable patients.

The life of "Madame Curie" is the life of a consummate scientist of the purest form. Her dedication to her work, family, country (both natural and adopted), and all of mankind is the substance of legend and heroism. 
Were she able to read this or any accolade, she would likely quietly dismiss such in her own humble way. She has been memorialized countless times, in the naming of universities, the awarding of honorary diplomas and fellowships, the receipt of countless awards, the making of coins and currency, and the naming of museums, and even a movie made of her life story. The list of her accomplishments, awards and legacy would fill many volumes; far too many to denote here.

Perhaps the most fitting description of Maria Sklodowska-Curie came from none other than the great scientist and mathematician, Albert Einstein who remarked: "Of all the celebrated beings, the only one whom fame has not corrupted".

\section{References}

1. Curie P, Curie M. Proceedings of the Academy of Science July 18, 1898.

2. Curie E. Madame Curie: A biography by Eve Curie. Doubleday, Doran and Company, Inc. Country Life Press, Garden City 1937.

3. Canonsburg, Pennsylvania Borough website: http://www. canonsburgboro.com/Curie-WebPage/.

4. National Institute of Science and Technology website: http: //www.nist.gov/pml/general/curie/index.cfm.

5. American Institute of Physics website: http://www.aip.org/ history/curie/contents_text.htm.

6. Viol C. The Story of Mme. Curie's gram of Radium. Radium 1921; 17: 37-52. 